\title{
Ries-slægten i Stenderup Fra Ries'ernes gård
}

Af $H$. P. Jensen

Det begyndte i Ribe, hvor den rige kantor ved Ribe Domkirke Anders Brok i 1458 skænkede to gårde i Kastrup by i Gram sogn til domkirken. Da han døde fem år efter, var der stadig meget at bortgive i et stort og prægtigt testamente.

Efter reformationen er de to gårde formentligt overtaget af kronen som så meget andet kirkeligt gods. På den ene af dem nævnes omkring 1550 Laurids Smed som "Kongelig Tiener" og i 1580 sandsynligvis sønnen Jens Nielsen. Derefter skiftes over til Toftlund kirkebog, hvor Jens Nielsens søn, Laurids Jensen fra Kastrup, født omkring 1610, den 25. marts 1656 ægter enken Karen Jeskone af Stenderup og rykker ind på hendes gård. Laurids dør 31 . aug. 170089 år gammel. I ægteskabet var der tre sønner og en datter. Alene sønnen Niels Lauridsen, født 3. juli 1664, interesserer. Han har mærkeligt nok tillagt sig slægtsnavnet Riese, der går videre til hans efterkommere. Niels Lauridsen Riese ægtede 16. maj 1700 Karen Jakobsdatter af Stenderup og opkaldte deres første barn, en søn, behørigt efter bedstefaderen som Laurids Nielsen Riese. Denne Laurids blev i 1733 gift med en Maren Jensdatter, og xgteparret fik tre sønner og to døtre. Sandsynligvis er fire af børnene døde som små. Der høres kun om pigen Bodil Lauridsdatter, der var født 19. nov. 1736, og som 22. okt. 1756 blev gift med Mads Andersen af Stenderup. Bodil døde kun 43 år gammel i 1779. Ægteparret fik fire børn, alle drenge, hvoraf en Andreas døde som spædbarn. Det var børnedødelighedens tidsalder; men overlevede man, var en meget høj livsalder ikke usædvanlig. Sønnen Laurids Madsen Ries, som efternavnet nu er kortet ned til, født 31. jan. 1761, førte slægten videre. 
Den 10. april 1786 udstedte den sessionsdeputerede på kongens vegne et fornemt hjemsendelsespas fra krigstjenesten for "National-Mousquetier« Laurids Madsen, der har tjent i seks år ved »Slesvigske geworbene Infanterie-Regiment som ærlig og troe, ærekier og tapper soldat. Anledningen var, at soldaten nu overtog sin gård. Allerede den 4. nov. 1785 havde Laurids Madsen Ries ægtet pigen Malena Mikkels af Stenderup, og da faderen Mads Andersen i november 1786 indgik sit andet ægteskab, er det tænkeligt, at han har måttet skifte med børnene og derfor afstået gården til den ældste søn og måske fraflyttet byen.

Malena Mikkels var af gammel Stenderup slægt. Broderen Hans Mikkelsen sad på en af byens gode gårde og var en tid lang sognefoged. Han var ugift, og ved hans død i 1804 kom en god arv også søsteren og hendes børn til gode.

Laurids Madsen Rieses gård var den nuværende Enggaard i Stenderup, lidt ude ad vejen fra Stenderup til $\varnothing$ rderup. Pladsen er sandsynligvis gårdens oprindelige, selv om det har betydet, at den har ligget noget uden for den stærkt sammenbyggede Stenderup by. Den var, som det senere navn også siger, en typisk enggård, der kunne føde en stor kvægbesætning både sommer og vinter. Dens areal omkring 1800 lader sig vanskeligt bedømme, da den i tidernes løb i Riesernes eje har været indblandet i flere magelæg, til- og frasalg. Dens nuværende areal er omkring 110 hektar, og den har næppe på noget tidspunkt været mindre. Af oplysninger fra skatteansættelser, skøder og boopgørelser kan gården bedømmes til netop at være eng- og kvæggård. Udsæd og kornbeholdninger er af beskeden størrelse; men hø er altid at finde i fag og på lofter. Man sagde også, at ejere af sådanne gårde kun havde to interesser: hø og stude, og gårdenes drift var enkel. Høbjergning i forsommeren, og kreaturpasning vinteren over. Sideløbende fandtes »mejergårde«, der havde store kohold og udnyttede mælken til smør og ost. Studegårdene havde ringe interesse $\mathrm{i}$ koholdet, der fordrede stadig og god pasning, og foretrak at købe det nye tillæg som kalve eller ungdyr. Studedriften bar derfor i sig selv spiren til en handelsvirksomhed, til eget brug og som formidling.

Laurids Madsen Ries ses $\mathrm{i}$ hele sin tid som ejer af gården $\mathrm{i}$ Stenderup at have handlet vidt og bredt. Han synes dog at have haft bestemte strøg, hvor han færdedes mest. Således slægtens gamle 
hjemsted Kastrup, men også Gabøl, Ørderup og Toftlund og så fjernt som Bredevad ved Ravsted, hvor hans datter Elsbe, født den 14. okt. 1787, i 1808 blev gift med gårdmand Hans Johannsen.

Handel forudsætter omsætningsmidler, enten rede penge, eller andre betalingsformer som veksler og obligationer eller formidling ved kaution overfor trediemand. Fra Laurids Madsen Rieses tid er bevaret to små notesbøger og en række notater, hvor han dels har opstillet afregninger over et stort antal handler fra få år, dels lavet en primitiv status ikke over gård og besætning, men over penge, han havde til gode eller skyldte bort. Fra omkring 1800 til hans død i 1809 ses han at have bevæget sig stadig mere over i pengeforretningerne. Tidens pengeforhold var forvirrede under Napoleonskrigenes inflation, og fordi flere møntsorter var gængse $\mathrm{i}$ hertugdømmet Slesvig i disse år. Der opereres med lybsk mønt, slesvig-holstensk courant, dansk sølv og seddelmønt. Et tilskud til velstanden, som aftegner sig af disse spredte optegnelser, der ikke har kunnet arbejdes sammen til et helhedsbillede, fik Laurids Madsen Ries ved Hans Mikkelsens død og boopgørelse i 1804. Dette bo foreligger næsten fuldstændigt $\mathrm{i}$ dokumenter og giver et fyldigt billede af forholdene på en Stenderupgård omkring 1800. Realisationen af boets mange ejendele blev varetaget af herredsfoged E. J. Clausen og Laurids Madsen Ries. - Den rentesats, der opereres med i de mange lån og transaktioner, bevæger sig fra tre til fire procent, uanset den stadige pengeforringelse. Den har man forsøgt at gardere sig mod ved omregning til sølvværdi af handelstallene, lejlighedsvis også ved pantesikring og forskellige bestemmelser om forudbetaling og klausuler i købs- og salgsaftaler.

Laurids Madsen Ries døde den 6. juni 1809. Datteren var da allerede flyttet fra stavnen som gift, og enken Malena sad tilbage med sønnen Mikkel Lauridsen Ries, der var født den 2. sept. 1793 og altså ved faderens død kun var 16 år gammel. Mikkel skrev senere sit navn som Michel Ries og ses undertiden som Michael Ries.

Der er sikkert tidligt kommet ansvar til den unge dreng; men han har haft evnerne til at bære det. Allerede omkring 1812-13 i Statsbankerottens forvirrede år ses han engageret $\mathrm{i}$ handel af den ene og den anden art, og gårdens drift indadtil og udadtil har sikkert påhvilet ham. Der foreligger kun ganske enkelte papirer, der kan kaste noget lys over disse år. Han har sikkert haft skuffelser 
ved hjemtagelsen af faderens udestående fordringer, der ses optegnet flere gange forud for faderens død, der kan være sket efter længere svagelighed. Også søsteren Elsbe i Bredevad måtte tilgodeses med fædrene arv, og genoprettelsen af et sikkert pengevæsen efter Statsbankerotten, der skete ved bankhæftelsen, en fast prioritet i sølv på al fast ejendom i landet til Nationalbanken, har sikkert hvilet tungt på den højt boniterede enggård $\mathrm{i}$ Stenderup.

I 1815 kom yderligere en vanskelighed til, idet Mikkel Ries da stod foran indkaldelse til militærtjeneste. Han havde imidlertid mulighed for at udnytte den ret, værnepligten gav en gammel mands eller enkes eneste søn til at købe sig en stedfortræder. Den 7. april 1815 skrev Mikkel Ries kontrakt med en Christian Sørensen af Haderslev om, at denne overtog tjenesten for 90 daler slesvigholstensk courant, en meget betydelig sum for den tid; men Mikkel Ries må have haft råd.

Den 9. okt. 1816 blev der skrevet skøde mellem enken Malena, salig Laurids Madsens, i Stenderup til sønnen Michel Ries, idet søsteren Elsbe, uanset tidligere modtaget, modtog 1600 rigsbankdaler i sølv, og der sørgedes for moderen ved aftægt og kontante penge. Bestemmelserne tyder på solid velstand, og det fremgår af skødet, at der på dette tidspunkt stod penge udlånt fra gården. Gården betegnes som en tre ottings gård eller trefjerdedelsgård. Indirekte $\mathrm{i}$ teksten spores gode familieforhold. Alt er ordnet $\mathrm{i}$ fordragelighed.

Mikkel Lauridsen Ries var så mand på gården og forblev det til en tidlig død som 40-årig den 2. maj 1833, altså i kun sytten år. Disse sytten år kan følges ret nøje, alene på bevarede slægtspapirer. Stoffet kunne sikkert uddybes yderligere i offentlige arkivalier. Det væsentligste af de private papirer er nogle få lommebøger, der har været regnskabs- og notesbøger for Mikkel Ries, et stort antal breve, dels af forretningsmæssig karakter, dels af privat til venner bosiddende rundt omkring i landet, og endelig også et stort antal tilfældige notater over de forskelligste emner. Mikkel Ries har været virksom på gården, men i øvrigt ustandseligt på farten, handlende med kreaturer og penge. Han synes at have begyndt kommissionsforretninger for større handelsvirksomheder, særligt i Flensborg, Hamborg, men også i Odense og Ribe. Hans handel har 


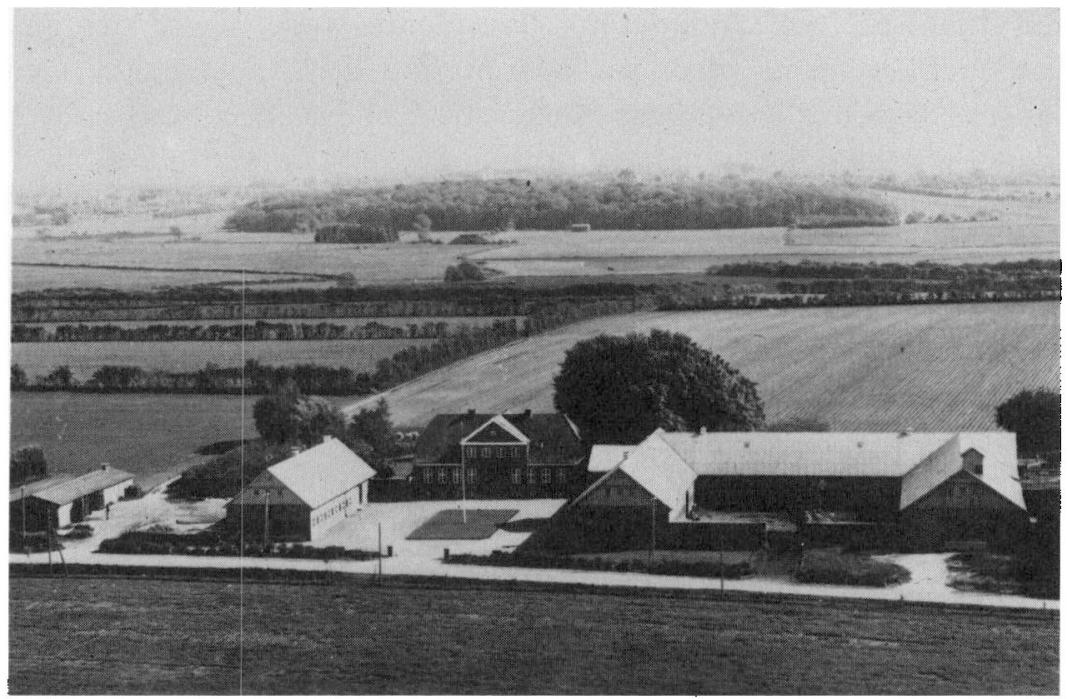

Riesernes gård i Stenderup $i$ sin nuvarende skikkelse som Enggärden, der nu ejes af Chr. Ludvigsen. (Privat eje)

dog udelukkende været med kreaturer og ikke med heste eller ejendomme. Hans pengeforretninger har omfattet et stort antal enkeltudlån, mange uden påviselig sikkerhed, men også ofte sikret ved kaution eller pant i fast ejendom. Størstedelen af kapitalen har givetvis været hans egen, men han ses dog ofte optage lån $i$ Toftlund, Branderup, Kastrup, $\varnothing$ ster Lindet og andre steder. Han har sikkert undertiden gjort dette for at være likvid, men det fremgår også, at folk med penge har betroet den ansete og pålidelige mand kapital for at få denne forrentet. Han har altså været regulær bankier. Det interessanteste i denne forbindelse er, at hans kaution øjensynligt har været et garantistempel, der anerkendtes, hvor han var kendt, og som regulært søgtes og købtes, på en måde en moderne bankgaranti.

Mikkel Rieses efterladte papirer tillader ikke et fuldstændigt og tilbundsgående billede af hans virke som handelsmand og bankier; men en række træk træder dog tydeligt frem. Ved siden af at forvalte og forbedre private formuesforhold, har han udført en funktion, der kan betegnes som samfundsmæssig før bankers og sparekassers tid. 
Folk som Mikkel Ries og samtidige af familierne Bjorholm i Ørderup, Thomsen i Roost, Refslund i Bovlund, Høyer i Agerskov og flere andre udførte i virkeligheden den pengeformidling, der dengang lå inden for primitive rammer på typiske landboegne, og som $\mathrm{i}$ vor tid er svulmet op til det uoverskuelige. Systemet rummede både godt og ondt. Et system var nødvendigt, dersom den stive naturalieøkonomi, hvor vare måtte byttes for vare, skulle undgås. Hvor kyndige og mådeholdne velhavende mænd røgtede deres mammon med rimelighed, gjorde de stor gavn. Hvor pengemagten udnyttedes til kras personlig fordel eller uigennemsigtige forretninger, der gik ud over ukyndige og svage, måtte systemet være et onde. Det personlige moment måtte altid være stærkt på godt og ondt, og i virkeligheden føltes det som en befrielse, da banker og sparekasser efterhånden i løbet af 1800-tallet kom ind som et upersonligt mellemled mellen kapitalejer og låntager og bragte de første en enkel og effektiv sikkerhed for pengene og de sidste længere låneperioder og sikkerhed mod tilfældige opsigelser og krav.

Mikkel Rieses eftermæle fra de få, men virksomme år, der var ham beskåret, er uplettet. Han har været dybt fortrolig med sin hjemegn, men synes ikke at have vist større interesse for anliggender uden for hans private sfære. Når dadelværdige forhold f. eks. vedr. skolen forebragtes ham, tog han affære og fik forholdene ordnede, men uden at gå hårdt til værks. Han synes at have haft interesse for tidens rørelser og at have læst en del. Hans vennekreds har været spredt og i det væsentlige uden for den snævre hjemby: Jes Bjorholm i Ørderup, en Raben i Odense, C. Philip Møller i Kastrup optræder oftest i de bevarede breve. Der var bøger i hjemmet i følge et sirligt katalog, skrevet af hustruen Anne Marie Kjær fra Ørderup. Der har været lagt vægt på børnenes uddannelse og opdragelse både før og efter hans død. Af mange enkeltheder mærkes et stærkt familiesammenhold og megen åbenhed over for omverdenen. Faderen rejste meget, og folk kom og gik i det gæstfrie hjem. De tre sønner var kun 13, 12 og 10 år, da Mikkel Ries døde; men det kan med sikkerhed eftervises, at han tidligt har søgt at opdrage til ansvar over for gård og familie og forstålse for handel og penges natur. Men som så ofte i sådanne hjem, var det moderen, der var mest betydende i forholdet til 
børnene, også fordi hun altid var hjemme. De skrev i voksen alder de mest hengivne og smukke breve til hende. I indbydelsesbreve fra slægt og venner bevidnes hun den mest udsøgte respekt og hengivenhed.

Mikkel Ries døde som kun 40-årig og så fjernt som for mere end 140 år siden. Hans person og levned kunne tilkomme en langt udførligere beretning. Den kunne sammenholdes med andre samtidiges. Mikkel Ries var $\mathrm{i}$ al sin velstand og med al indflydelse ingen sognekonge, der interesserede sig for det afgrænsede og bestemte alt dér. Han var heller ikke manden, der som Thomas Høyer i Agerskov, slægten Refslund i Bovlund, slægten Thomsen i Roost og andre kom til at formidle andet end penge mellem hjemstavn og omverden. Han var præget af den megen farten og kendte verden uden for Verona, men til forretningsmæssig fordel. Det rummelige og forståelsesfulde skinner ud af hans papirer. Han har været den søgte hjælper og rådgiver; men hans rolle har jævnligt været den uengagerede tilskuers. En vejledning kunne gives, et problem analyseres, men så måtte folk selv om resten. På en $\emptyset \mathrm{i}$ verden: Den store gård, i velstand, men flid og sammenhold, var det ikke sært, at slægten fik et legendarisk præg gennem mere end 100 år.

Mikkel Rieses navn var længe efter hans død et begreb langt udover hans Stenderup hjemstavn. Da Marten Refslund Poulsen i erindringsværket Minder i 1950 skulle beskrive det gamle englandbrug nævnte han Mikkel Rieses gård i Stenderup som eksempel. Da havde Mikkel Ries været død i mere end 100 år, og hans slægt var uddød på stavnen; men hans navn var og høres endnu knyttet til den store gård.

I roligt uskiftet bo - Anne Marie Ries, født Kjor, af Stenderup og bendes skifte med fem born.

Mikkel Ries af Stenderup døde den 2. maj 1833 efter en sygdom, hvis art og længde ikke kendes. I april måned samme år forsøgte han på et simpelt ark brevpapir at bistå hustruen for sidste gang: „Skulle jeg imidlertid i denne sygdom ved døden afgå - Du min gode kone. Sørg for, at børnene bliver godt opdraget og vænt til arbejde, thi lediggang virker ubestandighed.«

I den saglige tekst spores kærligheden til hustru og børn, og i 
dødens nærhed træder Mikkel Ries frem som et sjælsstort menneske.

På den store gård lå næppe fast gæld; men der fandtes en løs gæld omkring 1200 rigsbankdaler og tilgodehavender på 350. Det synes imidlertid, som om Mikkel Ries i de sidste år i overvejende grad havde helliget sig pengeforretninger, og at gårdens drift havde lidt herunder. Engbrugets komplicerede system af overrisling og udgrøftning beskrives som »i støkker«. Gårdens besætning var ved dødsfaldet unormalt lille, og konjunkturerne endnu vanskelige. Langt større vanskeligheder voldte dog den afdødes omfattende bankforretninger, der talmæssigt ikke kan opgøres nøjagtigt, men som formentlig har andraget mellem $4.800 \mathrm{og} 6.000$ rigsbankdaler, et betydeligt beløb for den tid. Mikkel Ries havde arbejdet med lånt kapital, der nu ved hans død overvejende blev opsagt. De tilsvarende udlån forsøgtes naturligvis tilsvarende opsagt og inddraget; men den sidste proces viste sig langt vanskeligere end forudset. Der blev lidt tab på et par skyldnere, og andre bad om udstrakt henstand. Anne Marie Ries løb således ind i en klassisk likviditetskrise uden at være insolvent. I nøden søgte hun hjælp hos Ørderupbønderne Wilken Nissen og Jes Bjorholm samt sognepræsten Jørgen Bjerregaard i Toftlund, der alle forstrakte hende med penge og troligt bistod hende $\mathrm{i}$ vanskelighederne. Endnu syv år efter mandens død måtte hun arbejde med veksler for betydelige beløb.

Disse tunge byrder og gårdens drift hvilede hårdt på Anne Marie Ries. Børnene måtte tidligt træde til, både med hårdt arbejde på gården og tidligt ansvar; men en stor styrke lå $\mathrm{i}$ familiens harmoniske samliv og sammenhold. I mange breve til og om hjemmet omtales hun med den største respekt, og børnenes breve og erindringer ånder dyb kærlighed til deres betydelige moder. Om de to ældste sønner Lorens og Andreas skriver hun ved en lejlighed, at de i en ung alder kun har kendt arbejde, men at de tidligt var landbrugs- og handelskyndige. Skolelæreren i Stenderup, H. J. Lagesen, senere den ældste søns svoger, bistod med privat undervisning af børnene, der alle fik udmærkede skolekundskaber. Den tredie søn, Klement Christian, kom i farverlære i Åbenrå og blev senere stamfader til den kendte Riesslægt i Åbenrå. Datteren Anna døde som barn. De to andre piger Magdalene og Elsbe kom $\mathrm{i}$ 
gode hjem i Nordslesvig og endog i det gamle land. Elsbe blev siden gift med købmand Hans N. Paulsen i Åbenrå.

Omkring 1840 bedredes landbrugskonjunkturerne, og gælden fra Mikkel Rieses bankforretninger var afviklet. Gårdens drift var inde $\mathrm{i}$ god gænge, og det store kvæghold genskabt. Familien begyndte at ånde lettet op.

Som naturligt var, hensad Anne Marie Ries i uskiftet bo. I 1842 var den ældste søn Lorens så vidt, at han skulle aftjene sin værnepligt, og det er da muligt indirekte at gøre status over familiens forhold. I en ansøgning til kongen beder enken om, at Lorens må fritages for militærtjenesten. Hun anfører da, at Lorens 22 år gammel, bestyrer gårdens drift, og at den næstældste Andreas hjælper hendes gamle fader på dennes gård i Ørderup. Den tredie søn er $\mathrm{i}$ lære, og pigerne endnu umyndige. Hun beder om, at Lorens må anses for gårdmandsenkes eneste søn, og at hun ikke har råd til at leje en stedfortræder for ham, da pengemangelen er stor. Det er imidlertid en klassisk undervurdering, og ansøgningen imødekommes da heller ikke. Den 14. marts 1843 indkaldes Lorens Ries til tjeneste ved 10. infanteribataillon $\mathrm{i}$ København.

Anne Marie Ries og hendes børn skulle imidlertid opleve endnu en stor vanskelighed, der varede fra 1845 til 1847, og som føltes særlig bitter, fordi den delvis beroede på uvenners giftige intriger. Naboen på den store gård, der nu hedder Stauninggård, men som dengang kaldtes Stenderupgård, var da Bohe Møller. I tidens røre bekendte han sig som ivrig slesvig-holstener og kom $i$ et stærkt modsætningsforhold til den danske Riesslægt. Der opkom flere stridigheder, der gik rettens vej. Arten af disse har ikke kunnet udfindes, men af senere magelæg de to ejendomme imellem kan ses, at der har været problemer med vej-, skel- og græsningsrettigheder. Bohe Møller indklagede Anne Marie Ries for herredsret og amtshus, og den 19. juni 1845 gav hun sønnen Lorens fuldmagt til at repræsentere hende $i$ alle henseender for ret og amtstue. Udfaldet af retstvisten kendes ikke, men indirekte nævnes Lorens' forstandige og selvbevidste optræden i retten. Fra 1844 havde herredsfogeden i Nørre Rangstrup herred været Friederich Ahlmann, der var overbevist slesvig-holstener og i de få år indtil 1848 sjælen i den tysksindede bevægelse i herredet sammen med ridefoged Riedell. Meget tyder på, at konfrontationen mellem de to Stenderup- 
slægter har udartet sig til et nationalt modsætningsforhold, og at Riesslægten derved har fået et spændt forhold til Ahlmann.

Mange af den efterfølgende sags enkeltheder er ukendte; men i efteråret 1846 fordrede amtshuset i Haderslev, at sønnen Lorens skulle tage fæstebrev på gården i Stenderup, og hans protest underkendtes. Den 26. okt. 1846 udstedte amtmanden Fr. Johannsen derfor fæstebrev til Lorens Ries efter hans fader Mikkel Ries på en 3 ottingsgård i Stenderup. Allerede den 11. november samme år tilpligtede herredsfogeden enken Anne Marie Ries at skifte mellem de 5 børn, der var levende. Fogdiets brev er ikke alene koldsindigt krævende, men den frist, der levnes til at gennemtænke og forberede et så betydningsfuldt skridt, ansættes til kun 11 dage, og inden da skal enken have udpeget formyndere for de umyndige børn. Et skifte forudsatte registrering og taksation af ejendommens værdier, hvoraf jord, en del af bygninger og beslag samt en del af gælden henhørte under fæstet, medens alt andet var til deling med fæstearvingens søskende. Ahlmanns person er vanskelig at bedømme i det nu følgende spil; men de meget korte tidsfrister, han gang på gang består på og delvis fremtvinger, kan kun betegnes som chikane.

Dette offentlige krav slog ned som et lyn i familien Ries. Allerede den 14. november sendte den i skolelærer Lagesens håndskrift og ved Wilken Nissens bistand indvendinger mod det retslige krav og anførte, at dersom fæstearvingen skulle tage værdierne efter den nuværende gunstige tid, ville han komme så dyrt hen, at han ikke kunne bestå i en ugunstig tid. Sådanne synspunkter har offentlige myndigheder imidlertid altid smilet af, og familiens brev affærdigedes kort. Derefter søgte familien bistand hos kyndige venner $\mathrm{i}$ Toftlund sogn, hos den allerede ansete Thomas Chr. Høyer i Agerskov og formentligt hos en af herredsfogdiets embedsmænd, der underhånden må have bistået familien. Disse hjælpere slår straks ned på det svage punkt $\mathrm{i}$ herredsfogdiets krav: at skifte $\mathrm{i}$ uskiftet bo forudsætter, at en af de myndige arvinger har krævet det, eller at deres omstændigheder ved fraflytning, giftermål o.l. er sådanne, at værdierne bør fordeles. Dette har ikke været tilfældet her. Myndige og umyndige bor alle hjemme og ingen er gifte og rettens indgriben er sket »ex officio uden anden anledning. Der indgaves straks en foreløbig klage, og en advokat Gottfrieding $\mathrm{i}$ 
Haderslev engageredes til fremover at føre sagen for familien. Advokaten indgav en formelig "protestation « med anmærkning om, at dersom herredsretten afviste denne, skulle den automatisk appelleres til den slesvigske overret i Slesvig.

Familien blev meget hurtigt klar over, hvor store vanskeligheder et skifte kunne medføre. I 1833 havde der endnu været deflationstider mod nu i 1845/46 opgangstider. De værdier, der var skabt i de forløbne år med konjunkturerne delvis i ryggen, var Lorens' fortjeneste. Skulle de nu deles, kunne man risikere at skulle genkøbe disse dyrt. Det var, hvad det var; men tabte han modet overfor nye byrder, stod hans moder stadig med en stor gård, der kun kunne drives på sønnens arbejdskraft, og tilmed endnu med umyndige børn. Det lykkes familien, trods Ahlmanns indædte modstand, at opnå henstand med registrering og taksation $i$ to måneder, og amtshus og overret var ikke vel tilmode, da sagen forelagdes, og der anordnedes særlige undersøgelser af dennes detailler. Ahlmann opretholdt imidlertid herredsrettens synspunkt, at skifte skulle ske, og den endelige afgørelse faldt derfor ved overretten i Slesvig i maj 1847 efter gentagne udsættelser af herredsrettens krav. Forholdet med de myndige arvinger, der ikke ønskede skifte og blev bistået af de umyndiges formyndere, har været ret enestående, og familien stod juridisk stærkt med henvisning til bestemmelserne om uskiftet bo og formynderskab fra 1742.

Den 4. maj 1847 resolverede Den Kongelige Slesvigske Overret på Gottorp Slot imidlertid, at herredsrettens kendelse skulle stå ved magt, omend med lempelser med hensyn til de værdier, der henhørte under fæstet, og de, der som privatejede skulle arveretligt fordeles. Det pålagdes familien Ries at lade registrering og taksation ske fyldest, og $\mathrm{i}$ juni samme år blev sådant da foretaget, og allerede den 17. juli 1847 gav enken Anne Marie Ries sammen med myndige og umyndige børn Lorens Ries skøde.

I det meget omfangsrige skøde påtager køberen sig al kendt og ukendt, fast og løs gæld på ejendommen. Han udløser alle levende søskende med penge, møbler, klæder og ophold, for så vidt de endnu bedst kan bo på gården. Moderen sikres en udførligt beskrevet og omfattende aftægt, herunder bolig i det såkaldte ovnhus. En gammel pige, Maren, der tro havde tjent familien også i Mikkel 
Rieses tid, blev sikret bolig, ophold og hjælp i sygdom. Teksten er udførlig og forretningsmæssig. Familien har holdt masken, da den nødtvungent var gået til biddet og nu måtte bede rettens "officiales" udfærdige og bevidne dispositionen. Men indirekte spores en næsten middelalderlig følelse for stavnen som grundlag for slægtens eksistens, der også omfattede pligter overfor tyende og til familien knyttede. Hvem der slutteligt var skødehaver var vel af betydning, men ikke altafgørende. Slægtens vel og stavnens opretholdelse gik forud.

En grundig gennemlæsning af skødeteksten lader formode, at familien har haft særdeles kyndige rådgivere. Den store aftægt, hvis udnyttelse moderen jo sluttelig selv var herre over, var en god ventil, der tillod regulering af gældens tyngde. Det kan skønnes, at en væsentlig del af gårdens værdier sluttelig er henført under fæstet, hvoraf der skulle svares en årlig afgift, men som ikke skulle købes. En bedømmelse af gårdens endelige købesum er ikke let; men de byrder, Lorens Ries påtog sig, var ikke ubetydelige. Senere erindrede han gårdkøbet som noget, der havde tynget ham. Den flittige og måske selvbevidste unge mand havde pludseligt følt omverdenen som noget fjendtligt og krævende, og han følte sig vel noget modløs overfor de mange pligter, der nu alene påhvilede ham. Året efter kom Treårskrigen og inflationerede alle priser op. Byrderne lod sig let bære. Men på egnen blev sagen ikke glemt med det samme. Herredsfogedens handlemåde føltes nævenyttig. Det kunne glemmes; men at plage en enke i så store anliggender med tidsfrister på nogle få dage, føltes simpelthen som retsdrejning, og harmen var stor. Der blev koldt omkring rettens embedsmænd, og i marts 1848 blev Ahlmann og Riedel bortjaget og fik ikke senere lov til at vende tilbage. Hele herredet sluttede op omkring $\mathrm{H}$. A. Krügers og kaptajn Jagds friskarebevægelse. Vandene var skilt. År efter sad Ahlmann i meget vanskelige forhold $i$ Krempe i Holsten og klagede sin nød for H. A. Krüger og Thomas Chr. Høyer. En Korrespondance med Krüger er gengivet i Morten Eskesens: Hans Krügers Saga, hvor Ahlmann belyser sin stilling i det nationale røre. Han var givetvis en dygtig jurist, og i korrespondancen træder han heller ikke frem som nogen dårlig mand. H. A. Krügers vrede kunne være som en byge brosten; men hans storsind var uomtvisteligt, og han hjalp den landflygtige. Ahlmanns rolle i dette 
spil er vanskelig at bedømme: En jurist, der kunne se paragraffer, men ikke ret? Eller redskab i en intrige, der kunne karakteriseres hårdt? Høyer var en stilfærdig mand, men kunne være glasklar: Han svarede Ahlmann: "At hensigten helliger midlet anses ikke for anerkendelsesværdigt. At midlerne, uanset deres juridiske rigtighed, skulle kunne hellige hensigten, næppe ejheller.« - Så var det sagt.

Anne Marie Rieses lange tid i roligt, uskiftet bo, som hun selv kaldte det under retsstriden, var forbi. På Riesernes $\emptyset$ i verden, gården $\mathrm{i}$ Stenderup, havde man måttet bøje sig, men ikke mistet sammenholdet. Alt efter rimelighed, som skødet sagde. Anne Marie Ries døde i 1868, agtet og elsket til sin dødsdag.

Lorens Ries kom til at sidde i 47 år som ejer af gården indtil 1894, og $\mathrm{i}$ hans tid nåede slægten Ries zenith.

\section{Lorens Ries og tiden efter ham}

Lorens Ries var født i 1820 og døde 1900 i Åbenrå efter at have siddet som ejer på slægtsgården fra 1847 til 1894. Fra hans tid foreligger så mange dokumenter, breve og optegnelser, at en udførlig biografi ville være mulig, omend med lakuner.

Fra hans unge år findes intet fotografi, derimod et fra omkring 1880 , der viser et skeptisk, nærmest mut ansigt med opmærksomt betragtende øjne. Han skulle for tidligt være voksen, skrev hans moder ved en lejlighed, og det er nok tænkeligt. De tidlige pligter efter faderens død i 1833, da han var 13 år gammel, og de store problemer han på moderens vegne måtte udstå 1845-47, gik ikke sporløst hen over ham. Han tiltrådte ejendommen med en følelse af mismod, og han bevarede livet igennem en skeptisk, afventende holdning over for meget omkring sig. Han var ingen heftig natur, men på vagt $\mathrm{i}$ alle forretningsanliggender og gav jæunligt råt for usødet. Han blev en meget forretningskyndig mand, men sikkert også en koldsindig mand med ar på sjælen. Hans børn fandt ham siden vanskelig at komme $\mathrm{i}$ kontakt med.

Sammen med broderen Andreas, der siden arvede morfaderens ejendom i Ørderup (nuværende Poul Rossens) deltog han i frihedsrøret i 1848, og begge brødre var alle dage danske. Men ellers helligede Lorens sig en årrække gården. Den var $i$ hans lange liv en 
basis, der skulle være $\mathrm{i}$ orden, uanset hvad han ellers indlod sig på. I 1850-erne ses han som deltager $i$ adskillige jordhandler $i$ kompagniskab med vennen Anders Th. Refslund på Løbækgård i Ørderup. Formålet har primært været en bedre arrondering af hans egen ejendom, men også fortjeneste ved udstykning og frasalg. Tilfældet ville, at hans gamle modstander Bohe Møller da var i vanskeligheder. Et stort byggeri på dennes gård var finansieret i sydslesvigske og holstenske adels- og advokatkredse i 1840-erne, og Møller

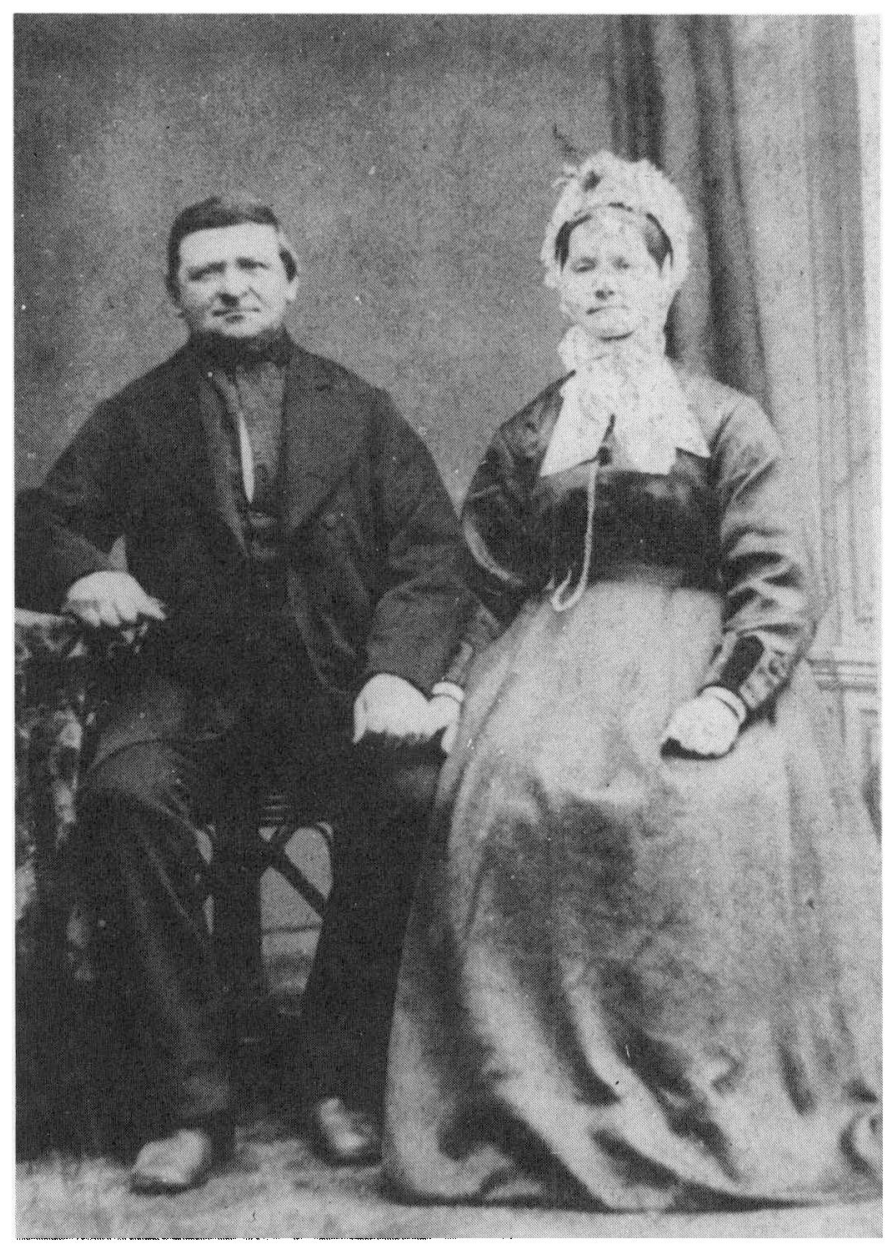

Egteparret Lorens og Marie Ries, fodt Refslund. (Privat eje) 
evnede ikke at efterkomme de betydelige forpligtelser, der i 1855 førte til en opsigtsvækkende tvangsauktion. Prioritetshaverne var en baron von Heintze på Nienhof i Holsten, senator I. G. Marcussen i Slesvig og advokat P. Hansen i Flensborg. Umiddelbart efter auktionen afkøbte Lorens Ries og Anders Th. Refslund de tre Bohe Møllers tidligere gård og skaffede øjensynligt med lethed de betydelige summer, der var tale om. Der har næppe været tale om nogen gengxldelseshandling, men kun om en forretningsmæssig disposition. Denne ejendom og andre vides at have bragt betydelig fortjeneste. Som et kuriosum kan nævnes, at vel lå Stenderup i Haderslev amt; men flere af byens ejendomme hørte dog som et levn fra en kirkelig fortid til Løgumkloster amt, der havde afløst det tidligere Løgum Kloster, og flere af disse handlers skøder er lyst i Løgumkloster.

Lorens Ries synes kun i ringe grad at have interesseret sig for den afdøde faders bankforretninger. Der gjorde derimod broderen Andreas, der $\mathrm{i}$ denne henseende førte slægtens interesser videre. Han var Agerskov Sparekasses første indskyder i 1863 med 2.000 rigsdaler, og i 1872 var han drivkraften bag oprettelse af en sognesparekasse $\mathrm{i}$ Toftlund, der i mange år havde domicil $\mathrm{i}$ Stenderup. Lorens Ries drev gården solidt, græssede en stor besætning, pløjede efterhånden lidt mere op, begyndte med kunstgødning og bedre plove. Bygningerne fik en stor forbedring $\mathrm{i}$ 1857; men tvangen til den helt intensive drift var der ikke. Der var indtægter uden for landbruget.

Efter indlemmelsen i det preussiske rige kom Slesvig ind bag de tyske toldmure, der år efter år voksede og blandt andet tilsigtede et produktionsdygtigt landbrug, der kunne brødføde den store befolkning i fred og især i krig. Trods periodiske kriser var årene fra 1870 frem til 1914 gode landbrugstider i Nordslesvig. Stigende kornpriser bevirkede megen nyopdyrkning, store drænsarbejder og udvidet brug af kunstgødning for at skabe kornjord; men også landsdelens gamle erhverv, kvægholdet, havde opgangstider. Markederne i de store nordtyske byer havde brug for tilførsler, som det lønnede sig at producere til. Der opkom derfor et stort behov for opkøb og formidling af kvæghandel. Lorens Ries slog ind på denne vej og udviklede sig fra midten af 1860-erne til en af Nordslesvigs største kvæghandlere. År ud, år ind færdedes han på 
hesteryg med pengekatten om livet over hele Nordslesvig. Hans lommebøger fra 1870- og 80-erne rummer næsten hver dag notater om $k ø b$ og salg, ofte $\mathrm{i}$ store partier. Hans organisationstalent må have været stort. Tilliden førte kunderne til ham; men forsendelserne, afregningerne og kontakten til solide aftagere synes at have været ordnet med utrættelig påpasselighed. Breve, telegrammer og løse sedler vidner om hans forbindelser til store handelshuse $\mathrm{i}$ Hamborg, Husum og endog England og lejlighedsvis Danmark. En enkelt markedsberetning dateret 14. okt. 1872 fra det store tyske firma G. Hagedorn \& Co's London kontor slutter næsten ydmygt: "Hoffentlich denken Sie vor Schluss der Saison noch an mich«. For et enkelt år kan opgøres en omsætning på mere end 1800 dyr, og der har givetvis været endnu større tal.

Et indtryk af Lorens Rieses besærning og handel har indirekte kunnet fås gennem dyrlæge Rasmus Bjorholms efterladte regnskabs- og notesbøger, hvor Lorens Ries optræder fra 1876 til 1894 som dyrlægens største kunde. Det samlede antal konsultationer løber op i mange hundrede, dels på gården i Stenderup, dels ved tilkaldelser til opkøbt kvæg nær og fjern. De sidste særligt i årene 1876-1888.

Det kan skønnes, at Lorens Ries har arbejdet udelukkende på egen kapital og hverken benyttet prioritetsoptagelse eller bankkredit af betydning, men da han i 1870 -erne søgte tilknytning til et pengeinstitut, var det mindre den lokale sparekasse end banker på østkysten og muligvis længere nede i Tyskland. Han måtte have en tidsvarende betjening med udenlandske betalinger, veksler og garantier. En forbindelse til Den Nordslesvigske Folkebank i Åbenrå kan konstateres, muligvis også til Haderslev Bank, som vennen Anders Th. Refslund benyttede.

I 1851 var Lorens Ries blevet gift med Marie Christine Refslund af den tysksindede Refslund eller Revslund slægt i Stenderup. I ægteskabet var der to sønner og fire døtre, der fik vidt forskellige livsskæbner. Fra talrige breve børnene imellen er det muligt at danne sig et indtryk af et storbondehjem sidst i 1800-tallet, indirekte også af den brydningstid landsbyen Toftlund da var inde i. Byen blev fra 1880 en lille hovedstad i midtlandet med en stor embedsmandsstand og mange tilflyttere.

Hjemmet beskrives i disse breve som autoritært og præget af 
faderens hyppige fravær. Der blev ofret meget på børnenes uddannelse. Den ældste søn Andreas studerede til tysk læge og bosatte sig senere i Flensborg, hvor hans efterkommere endnu lever. Meget af undervisningen skete ved huslærer, der i reglen var tyskuddannet uanset hjemmets danske indstilling. Pigerne lærte husførelse i gode hjem, bl. a. hos pastor Tiedje i Skrydstrup. Senere blev den ældste datter, Anna, gift med Henrik Jessen Refslund på Løbækgaard i Ørderup, der var indbegrebet af danskhed. To af pigerne blev gift i Tyskland. Den yngste Pauline forblev ugift og passede senere forældrene på deres gamle dage. Den yngste søn Niels Petersen Ries var udtalt dansksindet og fik senere gennem sit xgteskab med Johanne Mygind fra $\emptyset_{\text {ster Lindet forbindelse til }}$ grundtvigske frimenighedskredse. Hos flere af børnene spores et rastløst element. Slægten var i opbrud.

Lorens Ries forblev dansksindet og forholdt sig afvisende over for den tysksindede svoger H. P. Refslund i Stenderup og hans meningsfæller. Men til hjemmets vennekreds hørte flere tyske embedsmænd, blandt andre amtsdommer Storm i Toftlund, søn af digteren Theodor Storm. Lorens var på én gang udpræget verdensvant og Stenderupbonde; men ved flere lejligheder har han givet udtryk for, at noget $i$ livet var gået ham forbi. Han havde måttet tage tidligt ved. Det var aldrig blevet til længere ophold $\mathrm{i}$ Danmark, højskoleophold og læsning. Han havde kun pengeforstanden at byde på, og forældrene følte sig ensomme. På hjemegnen stod der glans om hans store gård og position; men han fik ikke som broderen Andreas betydning for by og sogn. Denne havde arvet moderens noble og hjælpsomme sind, hvor Lorens måtte forblive den ensomme.

Først i 1894, da Lorens var 74, afstod han gården til den kun 22årige Niels og bosatte sig som rentier i Åbenrå, hvor han havde forbindelse til broderen Klements efterkommere. Niels Petersens Rieses billede er meget varieret. En søster har i et brev nævnt, at mange fandt ham genial; men for hende var han en forkælet dreng. Han havde arvet faderens handelstalent, men ikke oplevet dennes hærdende ungdom. Om han var den berømte spreder, der efterfølger slideren, spareren og samleren, tilkommer ikke os at dømme; men en trang til spænding har givet ligget i hans karakter. Han mindes som en rask, velbegavet og meget charmerende mand, 
der kunne underholde et selskab, så det længe huskedes og med en sjælden evne til at udtrykke sig kort og bramfrit. Bemærkninger, han har ladet falde for firs år siden, huskes endnu. Enkelte nulevende, der har tjent hos ham, husker hans lune og vid, men også at han var præget af uro og måske overmod. Han levede sikkert noget hårdt; men der var også nok at tage af. Han var kendt for hurtig og dristig kørsel med urolige heste, og det blev hans skæbne. Hans tragiske endeligt fængslede længe efter sindene, og med fejl og fortrin mindedes han altid som en usædvanlig mand.

I begyndelsen af oktober 1904 holdt han med hest og vogn ved Stenderup smedie. Derefter er enkelthederne omstridte, om hesten slog op, eller en skagle knækkede og brækkede hans ene ben. Han fik et svært sår, som gav stivkrampe. Han blev lagt i en kassevogn med halm og i huj og hast kørt til Kreiskrankenhaus i Haderslev, hvor man amputerede benet. Hans tilstand var fortsat alvorlig, og flere gange opsatte han og hustruen Johanne testamente, der kendes. Det er gribende ud af den tørre tyske notarialtekst at fornemme den raske og stolte mands resignation. Døden kom den 28. okt. 1904, og han var kun 32 år gammel.

Gammel tid målte den afdødes betydning og det indtryk, en dramatisk livsskæbne og død gjorde på samtiden, på gravfølgets størrelse, f.eks. antallet af hestekøretøjer. Rentier Sophus Hübschmann i Toftlund så som lille dreng Niels Petersens Rieses følge strække sig hele vejen fra gården i Stenderup med den xldgamle Stenderup kirkevej til Toftlund kirke. Der skal have været omkring 160 køretøjer. Han blev begravet i Riesernes gamle gravsted på Toftlund kirkegård, og på hans grav sattes en brudt søjle. Lorens Ries var død i 1900. Moderen fulgte efter den 1. maj 1906. Begge blev begravet i Åbenrå, hvor de havde tilbragt deres sidste år. Johanne Ries overlevede sin mand i mange år, sidst i Øster Lindet. Hun skildres som en smuk og indtagende kvinde. Ægteskabet var barnløst.

Riesernes gård blev derefter købt af Peter Rossen fra Gestrup, der måtte opleve første verdenskrigs forarmelse og de vanskelige tyvere. 1926 brændte gården, og dens genopbygning i herregårdsstil var et særsyn og er nok stadig egnens stateligste gårdbillede. Efter Peter Rossens død i 1931 overtog Handelsbanken gården og solgte i 1934 til Jørgen Ludvigsen fra Sandet, der i 1938 gav gården navn 


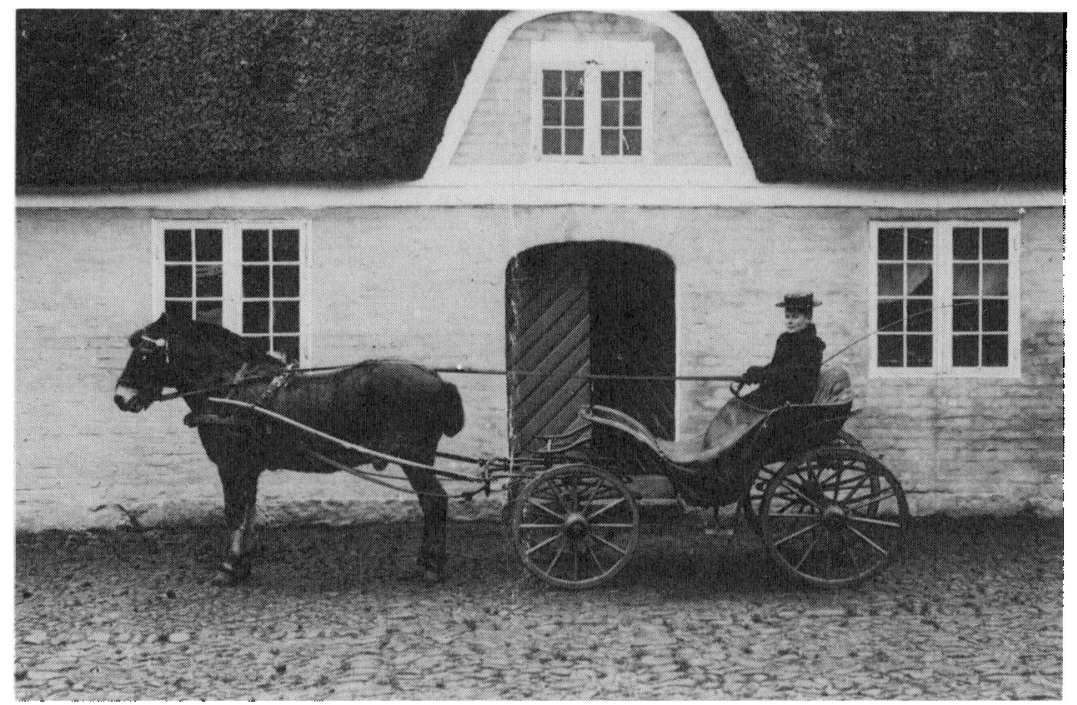

Jobanne Ries, fodt Mygind, foran boveddøren til Riesernes gård i Stenderup. (Privat eje)

som Enggården. En ny sliderslægt var på den gamle gård og fik med årene også den sande landmands livsløn: at se det gå fremad år for år. Driften var nu gængs. Fortidens høavl og studehold forsagedes til fordel for det alsidige landbrug. I 1971 afstod Jørgen Ludvigsen gården til sønnen Christian Ludvigsen.

Den sidste rest af Riesernes $\emptyset$ i Stenderup var slægtens gravsted på Toftlund kirkegård, men også det er nu sløjfet. De udviskede tavler på de gamle grave og den brudte søjle minder ikke mere om slægten og dens saga.

\section{Slagten Ries $i$ en national brydningstid}

Lorens Ries og hans søskende var danske. Deres børn kom til at leve $i$ en national brydningstid op til første verdenskrig, og den gik ikke sporløst hen over dem. Det kendteste navn af dem er nok senatoren Thomas Ries, hvis politiske brevskrivning blev behandlet af G. Japsen i Sønderjyske Årbøger 1976. Denne skildring skal dog holde sig til Lorens og Maria Christine født Refslunds seks børn, der alle forlængst er døde. Kilderne er først og fremmest sønnen Andreas Christian Ries’ barndoms- og ungdomserindrin- 
ger, der er nedskrevet omkring 1940. Dernæst en mere eller mindre tilfaldigt bevaret korrespondance mellen de seks søskende og endelig en række mundtligt gengivne erindringer fra slægtninge og tjenestefolk, der levede indtil for få år siden.

Ud af disse kilder kommer billedet af den store gård, der hvilede i sig selv. Piger, karle, dyr, livet på landet. Det regelbundne liv. Den store have. Høslettiden. De få rejser til bys: Toftlund, Åbenrå og en enkelt gang til Flensborg. De store stuer med Green ur, mahognichatol og statelige sofaer. Porcelæn og sølvtøj på de festlige borde, når den vidt forskellige bekendtskabs- og vennekreds kom på besøg. De mange danske dag- og ugeblade. Husmoderen, der erindres af tidligere tjenestefolk for god og rigelig madlavning og mild overbærenhed. Øverst i tavs lidt tvær majestæt familieoverhovedet, Lorens Ries. Jævn af væsen og levemåde, men med penges stille respekt om sig, og gnavent ventende at alt skulle gå efter hans hovede.

Hustruen var ud af den tysksindede Revslund slægt. Hendes broder Peter Revslund, der ejede en gård i Stenderup, karakteriseredes af Andreas Christian Ries som »sehr eigenwillig. Frühzeitig und intensiv deutsch«. Nok til at den kompromisløst danske Lorens Ries afbrød enhver forbindelse med ham.

Ældst af børnene var datteren Anna (1855-1931), siden gift med Hendrik Jessen Refslund. Ifølge alle søskendes udsagn var hun den, der lignede faderen mest af sind og skind, og hun var sålænge han levede hans fortrolige. Mange år efter huskede den ene og den anden af børnene med fortrydelse, hvor meget faderen havde talt med Anna og hvor lidt med dem. Hun var uomtvisteligt dansk, og som flere af hendes søskende ændrede nationalt sindelag eller flyttede til Tyskland, afbrød hun forbindelsen med dem.

Derefter fulgte to drenge, der døde som små, og i rad tre piger. 1869 fødtes sønnen Andreas Christian Ries og slutteligt Niels Petersen Ries i 1872. Datteren Pauline forblev ugift og blev boende hos forældrene, også da de flyttede til Åbenrå. Hun var en af de tro sjæle, der efter tidens skik, ofrede sig for forældrenes pleje på de gamle dage. Andreas Christian Ries kaldte hende tysk.Søsteren Maria Laura beretter i et brev, at faderen »duldete kein deutsch im Elternhaus", og at hun var dansksindet.

Næste søster var Mikelia, der fik en meget bevæget livsskæbne. 
Gang på gang omtales hendes skønhed og strålende livfuldhed, der lod hende gå ind i folk med træsko på. Hun var gift tre gange. Første gang med Martin(?) Andresen, broder til den kendte indremissionske pastor Carl Andresen i Agerskov. Efter hans tidlige død giftede hun sig anden gang med en gymnasielærer Juhl ved Latinskolen i Haderslev. Det sidste ægteskab var med en Oberstudienrat Stölting i Hamborg. Hun havde kælenavnet Tante Kille og blev flittigt opsøgt af nevøer og niecer, der længe mindedes den muntre, fordomsfrie stemning $\mathrm{i}$ hendes hjem. Hendes nationale sindelag kendes ikke; men hendes bohèmesind har næppe fæstnet sig ved sådant, efter at hun flyttede fra Nordslesvig.

Derefter fulgte Maria Laura, der blev gift med en tysk embedsmand Hempel. Han gjorde en stor karriere og endte som Regierungsrat i Baden, hvor hun som enke tilbragte de sidste år i Sankt Blasien i Schwarzwald. Hun og hendes mand havde ry af gode økonomiske kår og en fornem, men stilfærdig levevis. Hun kaldtes den kloge søster, og i flere breve træder hun frem som et begavet og afklaret menneske. I brevene mindes med en blanding af kritik og vemod barndomshjemmet, forældrene, de to brødre og forholdene $i$ det fjerne Nordslesvig for mange år tilbage. De nationale forhold var noget fjernt og overlevet for hende.

Under børnenes opvækst holdt ægteparret Ries i reglen huslærer efter tidens skik. Det var i nogle år en dansk frk. Emmy Nybro; men ejendommeligt og uden kendt grund blev hun i slutningen af 1870 erne afløst af tyske lærere. Motivet har sikkert været, at børnene skulle have en uddannelse, der kunne bruges i det land, de nu levede i. Alligevel kan dette forhold undre, Lorens' danskhed taget $\mathrm{i}$ betragtning; men der har øjensynlig ikke været tanker om at søge uddannelse i Danmark. Efter konfirmationen kom pigerne i huset hos den kendte pastor Tiedje i Skrydstrup for at lære praktisk husførelse og »Benimm«. Dermed var der lukket op for en tysk påvirkning ind $\mathrm{i}$ det ellers så aflukkede danske hjem.

Havde der været bonde i sønnen Andreas Christian Ries, havde der måske siddet en Ries på gården i Stenderup endnu; men hans lyst stod til bogen. Han voksede op i hjemmets danske sindelag, som han senere omtalte med stor loyalitet og forståelse. I $1885 \mathrm{kom}$ han på Latinskole i Flensborg, og fra første dag synes han med liv og sjæl at have indstillet sig på en tysk akademisk uddannelse. Efter en 
glad og flittig studietid og nogle års praksis nedsatte han sig i $1900 \mathrm{i}$ Flensborg som praktiserende læge. Han blev gift med Anna Katharine von Hielmcrone og blev boende i Flensborg til sin død i 1946. Under alle omskiftelser forblev han bevidst tysksindet. Han omtales som en dygtig læge og et meget tiltalende menneske. I Flensborg boede medlemmer af familien Paulsen fra Åbenrå, som hans faster Elsbe var gift ind i. De hørte til byens fremtræedende danske. Fru Aje Rolskov, et barnebarn af Lorens Ries, besøgte begge familier gennem mange år og omtalte dem som sine danske og tyske fætre.

Endelig var der den yngste søn Niels Petersen Ries, hvis livsløb er beskrevet. Han tilbragte barndom og den meste ungdom i det danske hjem. Hans hustru var af den dansksindede, grundtvigprægede Mygindslægt fra $\emptyset$ ster Lindet. Gennem hende fandt han over til Bovlund Frimenighed. Hans danske sindelag har været det nedarvede og selvfølgelige.

Sindelagsbrydninger inden for den enkelte familie under Fremmedherredømmet var jo ingenlunde usædvanlige. Hvad der i familien Ries' tilfælde må interessere er den rodløshed og fremmedartethed, der $\mathrm{i}$ løbet af få år afløste noget, der måtte synes så grundmuret og rodfæstet. I den modne alder synes de seks søskende næsten ikke at have kendt hinanden. Jæunligt spores $\mathrm{i}$ brevene ikke alene ligegyldighed, men antipati. Barndomshjemmet havde ikke magtet at bibringe nogen følelse af fællesskab. Kun den glade Tante Kille kunne løse op for noget af det følelsesbundne, når hun en enkelt gang viste sig hjemme eller hos søskende. Den stive Lorens tøede op, og selv den myndige Anna på Løbækgaard kunne ikke stå for hende.

I 1947 sendte Maria Laura Hempel et kondolencebrev til læge Hans Ries i Flensborg i anledning af faderen, Andreas Christian Rieses død. Hun mindedes da barndomshjemmet: Der var koldt hos os. Mellem os og forældrene var der en stor afstand. Trods det var det et hjem med meget godt og stor frihed; men vi talte for lidt sammen. Siden klagede forældrene over, at vi aldrig fortalte dem noget. Men det havde de ikke lært os som små, og nu kunne vi ikke mere lære det. Far var aldrig hjemme, og mor havde så meget at gøre. Vi måtte gøre, hvad vi ville, men ikke volde besvær.

At forstå alt, er at tilgive alt. Lorens Ries blev så tidligt faderløs, 
og hans unge år havde været kamp og ansvar. Han havde ikke selv fået lov at være barn, som hans moder rigtigt så.

Hans hustru omtales altid som stille. Hun havde ikke noget at skulle have sagt i skyggen af $x$ gtemandens dominerende personlighed. Hvad der manglede i fællesskab om børnenes opdragelse, søgte hun at opveje med en omsorg, der trods al travlhed blev til forkælelse. Den tåltes ringest af den søn, der skulle have ført slægtens gamle stavn videre. - Barndomshjemmet gav kun liden ballast med. De indtryk, børnene mødte senere i livet, blev de alt afgørende.

Slægten Ries er forlængst udslukt på dens hundredårige hjemegn i Toftlund sogn. Efter at dens gravsted på Toftlund kirkegård er slettet, er det sidste synlige minde om den forsvundet. 